\title{
Proline Content and Protein Patterns in Eucalyptus grandis Shoots Submitted to High and Low Temperature Shocks
}

\author{
Gustavo M. Souza ${ }^{1 *}$, Victor J. M. Cardoso ${ }^{2}$ and Antonio N. Gonçalves ${ }^{3}$ \\ ${ }^{I}$ Departamento de Ciências Biológicas; ESALQ/USP; C. P. 9; 13418-900; Piracicaba - SP - Brazil. ${ }^{2}$ Departamento \\ de Botânica; Instituto de Biociências; UNESP; C. P. 199; 13506-900; Rio Claro - SP - Brazil. ${ }^{3}$ Departamento de \\ Ciências Florestais, ESALQ/USP, C.P.l 9; 13418-900; gumaia@universiabrasil.net; Piracicaba - SP - Brazil
}

\begin{abstract}
Proline content and protein patterns changes in response to temperature shocks of both acclimated and non acclimated E. grandis shoots cultivated in vitro were investigated. Analysis of soluble proteins through SDS-PAGE and proline were carried out after $12 \mathrm{~h}$ at $12^{\circ} \mathrm{C}$ (cold acclimation) or $33^{\circ} \mathrm{C}$ (heat acclimation), and immediately after temperature shocks at $41^{\circ} \mathrm{C}$ and $0^{\circ} \mathrm{C}$. Analyses were also performed $24 \mathrm{~h}$ after the temperature shocks (recovery period). Temperature treatment at $0^{\circ} \mathrm{C}$ did not change soluble protein patterns both in acclimatized and non acclimatized plants, whereas cold temperature induced high proline levels, which kept relatively high after recovery period. Three novel, probably HSPs, proteins (90.5, 75 and $39 \mathrm{kDa}$ ) were observed in both acclimated and non acclimated plants submitted to high temperatures. Plants exposed at $41^{\circ} \mathrm{C}$ were able to recover from heat shocks after 24h, whereas they did not recover completely from cold shocks. The effect of the acclimation period on the recovering (homeostasis) varied depending on the parameter evaluated, and type and duration of the temperature shock.
\end{abstract}

Key words: Heat shock protein, proline, recovery, stress, temperature shock

\section{INTRODUCTION}

Adaptation to environment fluctuations is a major condition for the survival of plants. It is known that temperature changes may cause damages to the plant tissues, and the capacity of plants to acclimate metabolic processes to changing temperatures may account for their tolerance and resistance to extremes of temperatures. This implies that plant develops tolerance against the stress factor, such as high temperature, that causes injury. The capacity of acclimation in plants seems to be related to native habitat temperatures, with plants widely distributed having greater capacity of acclimation than plants with restricted distribution areas (Tobiessem, 1976; Nilsen and Orcutt, 1996).

The capacity of living organisms to hold their stability by adjusting their metabolism in order to avoid severe injuries due to environmental disturbances is referred as homeostasis. According to Møller and Swaddle (1997), homeostasis is a general expression indicating the tendency of the internal environment of an organism to be maintained constant despite environmental changes.

Plants respond to temperature changes through several mechanisms such as synthesis of heat and cold shock proteins (Howarth and Skot, 1994; Gimalov et al., 1996; Sabehat et al., 1996), and

\footnotetext{
* Author for correspondence
} 
aminoacids (Chapin, 1991; Santarius, 1992; Kuznetsov and Shevyakova, 1997). According to Arora and Saradhi (1995) and Hare et al. (1998), proline accumulation in plant tissues may increase the plant tolerance to several stresses, such as temperature stress.

Eucalyptus grandis is natural to the east coast of Australia, and is one of the most important commercial eucalyptus, with more than 1.5 million hectares planted in tropical and subtropical areas on four continents (Jacobs, 1976). Intensive planting programs have been carried out in Brazil for cellulose industry and forestation. The climate in the Australian native range of E. grandis is humid subtropical with mean minimum temperatures ranging from 2 to $10^{\circ} \mathrm{C}$ and mean maximum from 24 to $30^{\circ} \mathrm{C}$ (Barros et al., 1991).

The objective of this study was to verify the capacity of acclimated and non acclimated $E$. grandis shoots to respond to temperature shocks. Therefore, protein and proline changes were evaluated as an index of thermal stress, and the homeostatic capacity of these biochemical parameters was considered.

\section{MATERIAL AND METHODS}

Eucalyptus grandis Hill (ex. Maiden) shoots were grown under sterile conditions in glass flasks $(200 \mathrm{ml})$ with $40 \mathrm{ml}$ of nutrient culture medium (Correia, 1993), supplied with 3\% (w/v) sucrose, 2 $\mathrm{mgL}^{-1} 6$-benzylaminopurine and $0.5 \%(\mathrm{w} / \mathrm{v})$ agar.

Flasks were maintained in a controlled environment cabinet at $25 \pm 1^{\circ} \mathrm{C}$ under $12 \mathrm{~h}$ light period with photosynthetic active radiation of 50 $\mu \mathrm{mol} \mathrm{m} \mathrm{s}^{-2}$, and $12 \mathrm{~h}$ dark period. After 20 days, shoots were exposed independently to $41^{\circ} \mathrm{C}$ and $0^{\circ} \mathrm{C}$ for one or three hours. Half of the lot submitted to heat or cold shocks was subjected previously to $12 \mathrm{~h}$ acclimation period at $33^{\circ} \mathrm{C}$ and $12^{\circ} \mathrm{C}$, respectively. After thermal shocks, the plants were kept at $25^{\circ} \mathrm{C}$ for $24 \mathrm{~h}$ (recovery period). The scheme of the cold and heat shock treatments is shown in Fig. 1, with arrows indicating the time for collecting samples for analysis. Ten samples per treatment were collected.

Proline was extracted from 500mg samples ground in $10 \mathrm{~mL} 3 \%$ sulphosalicilic acid, and contents were determined according to Bates et al. (1973).
Proteins were extracted according to Souza et al. (1999). Samples (300 mg of plant material) were ground in liquid nitrogen and macerated in $5 \mathrm{~mL}$ extraction medium containing $4 \mathrm{~mL}$ TRIS- $\mathrm{HCl} \mathrm{pH}$ 6-8, $1.6 \mathrm{~mL} \mathrm{0.5 \%} \mathrm{(w/v)} \mathrm{2-mercaptoethanol,} 6.4$ $\mathrm{mL} 10 \%(\mathrm{w} / \mathrm{v})$ SDS, $3.2 \mathrm{~mL} \mathrm{2 \%}(\mathrm{w} / \mathrm{v})$ DMSO, 3.5g PVPP, 0.35g PMSF, $6.4 \mathrm{~mL} 10 \%(\mathrm{w} / \mathrm{v})$ glycerin and $10.4 \mathrm{~mL}$ distilled water. After $1 \mathrm{~h}$ at room temperature, the extracts were boiled at $100^{\circ} \mathrm{C}$ for $3 \mathrm{~min}$. After centrifugation at 10,000 rpm, the supernatant was recovered for eletrophoresis. One dimensional SDS/PAGE was carried out using $15 \%$ polyacrilamide gel with $20 \%$ SDS. The eletrophoresis was run at $35 \mathrm{~mA}$ for 3 hours. Gels were stained with comassie blue R 350 (PhastGel Blue R, Pharmacia-Biotech).

The experiments were run in triplicates, significance test were ANOVA $(p<0.05)$ and Tukey $(p<0.05)$. A completely randomized experimental design was utilized.

\section{RESULTS}

E. grandis shoots maintained at $25^{\circ} \mathrm{C}$ and then exposed $1 \mathrm{~h}$ and $3 \mathrm{~h}$ to $0^{\circ} \mathrm{C}$ showed a significant increment of proline content as compared to constant $25^{\circ} \mathrm{C}$. However, the level of proline was higher after $1 \mathrm{~h}$ under $0^{\circ} \mathrm{C}$ than under $3 \mathrm{~h}$ of cold condition.

The shoots exposed to $12^{\circ} \mathrm{C}$ for $12 \mathrm{~h}$ (acclimation treatment) prior cold treatments, showed higher increases in proline content, compared to non acclimated shoots, when submitted to cold shock for 1 and $3 \mathrm{~h}$ (Fig. 2). When cold treated shoots were returned to $25^{\circ} \mathrm{C}$, proline levels tended to hold high levels, such as those observed after the cold shock. In both acclimated and non acclimated treatments, proline levels did not return to the initial (prior cold shocks) condition (Fig. 2).

Eucalyptus shoots grown at $25^{\circ} \mathrm{C}$ were transferred to $41^{\circ} \mathrm{C}$ and proline content were evaluated after $1 \mathrm{~h}$ and $3 \mathrm{~h}$. A significant increase in the concentration of proline in the heat treated shoots were observed in response to the $41{ }^{\circ} \mathrm{C}$ treatment (Fig. 3). A $33^{\circ} \mathrm{C}$ treatment (heat acclimation) prior heat shocks did not change significantly proline concentration in the tissue after $1 \mathrm{~h}$ and 3 hours exposure of the plants at $41^{\circ} \mathrm{C}$ (Fig. 3). 
$\mathbf{A}$
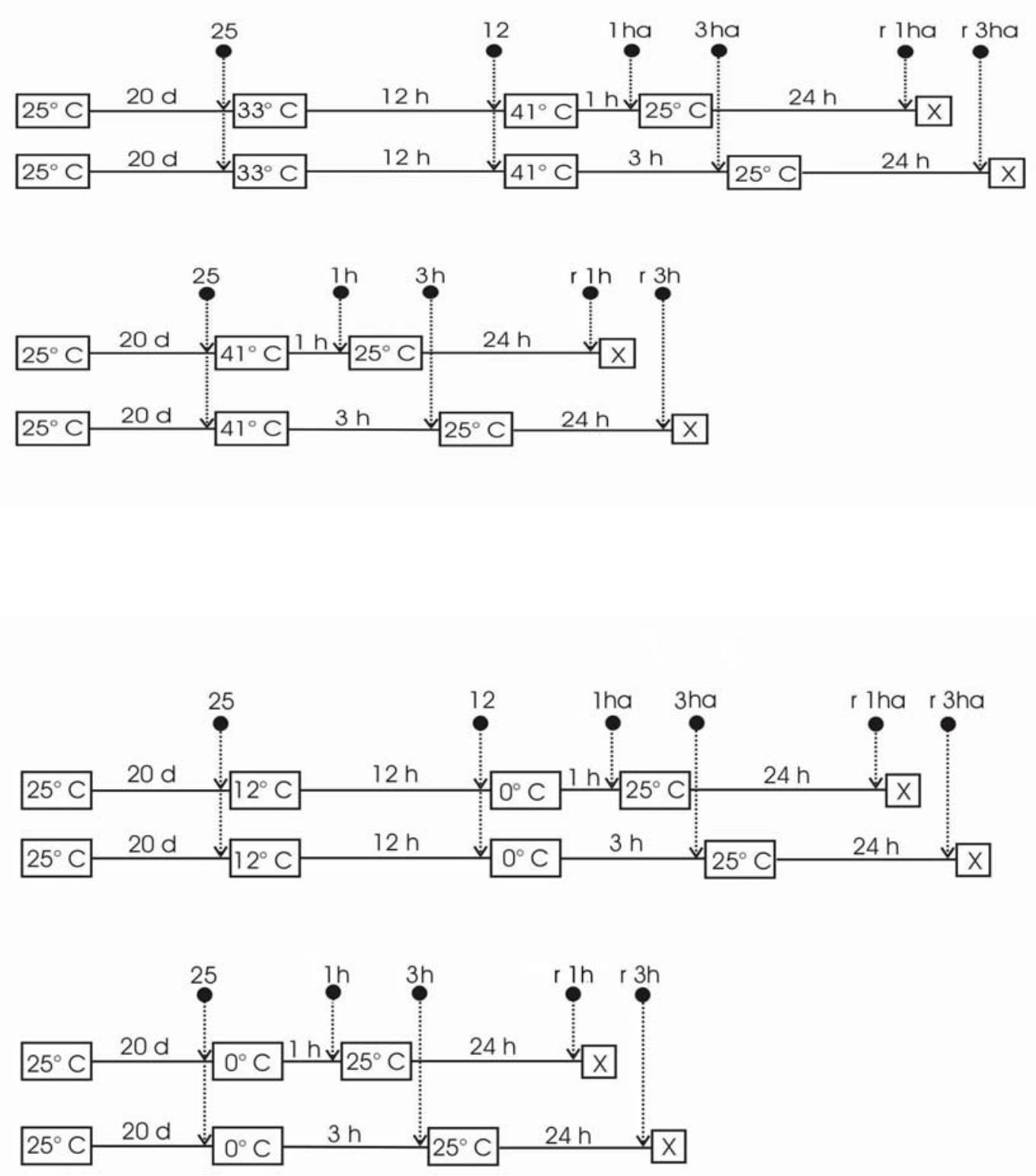

Figure 1- Experimental design of the heat shock (A) and cold shock assays (B). Dashed lines show time for samplings: $25=$ control prior temperature shifts; $12=$ after 12 hours acclimation period at $12^{\circ} \mathrm{C}$ or $33^{\circ} \mathrm{C} ; 1 \mathrm{~h} / 3 \mathrm{~h}=$ after $1 \mathrm{~h} / 3 \mathrm{~h}$ hours at $0{ }^{\circ} \mathrm{C}$ or $41^{\circ} \mathrm{C}$, with no acclimation; $1 \mathrm{ha} / 3 \mathrm{ha}=$ after $1 \mathrm{~h} / 3 \mathrm{~h}$ hours at $0^{\circ} \mathrm{C}$ or $41^{\circ} \mathrm{C}$, with acclimation; $\mathrm{r} 1 \mathrm{~h} / \mathrm{r} 3 \mathrm{~h}=$ after $24 \mathrm{~h}$ recovery period at $25^{\circ} \mathrm{C}$ following $1 \mathrm{~h}$ or $3 \mathrm{~h}$ temperature shocks, with no acclimation; $\mathrm{r} 1 \mathrm{ha} / \mathrm{r} 3 \mathrm{ha}=$ after $24 \mathrm{~h}$ recovery period at $25^{\circ} \mathrm{C}$ following $1 \mathrm{~h}$ or $3 \mathrm{~h}$ temperature shocks in acclimated shoots. $\mathrm{X}=$ end of the assay. 


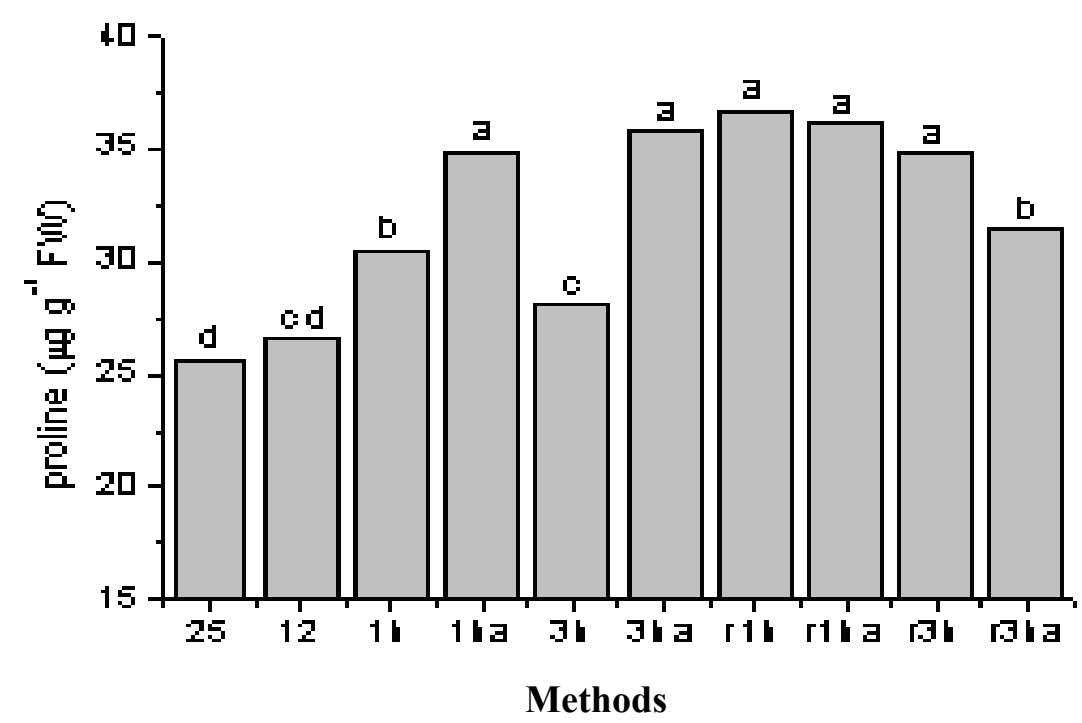

Figure 2 - Changes in proline concentration from Eucalyptus grandis shoots submitted to cold shocks. Small letters compare the mean of five repetitions (Tukey $p<0.05$ ). Treatments are detailed in Fig. 1. Each point represent the average of five replicates.

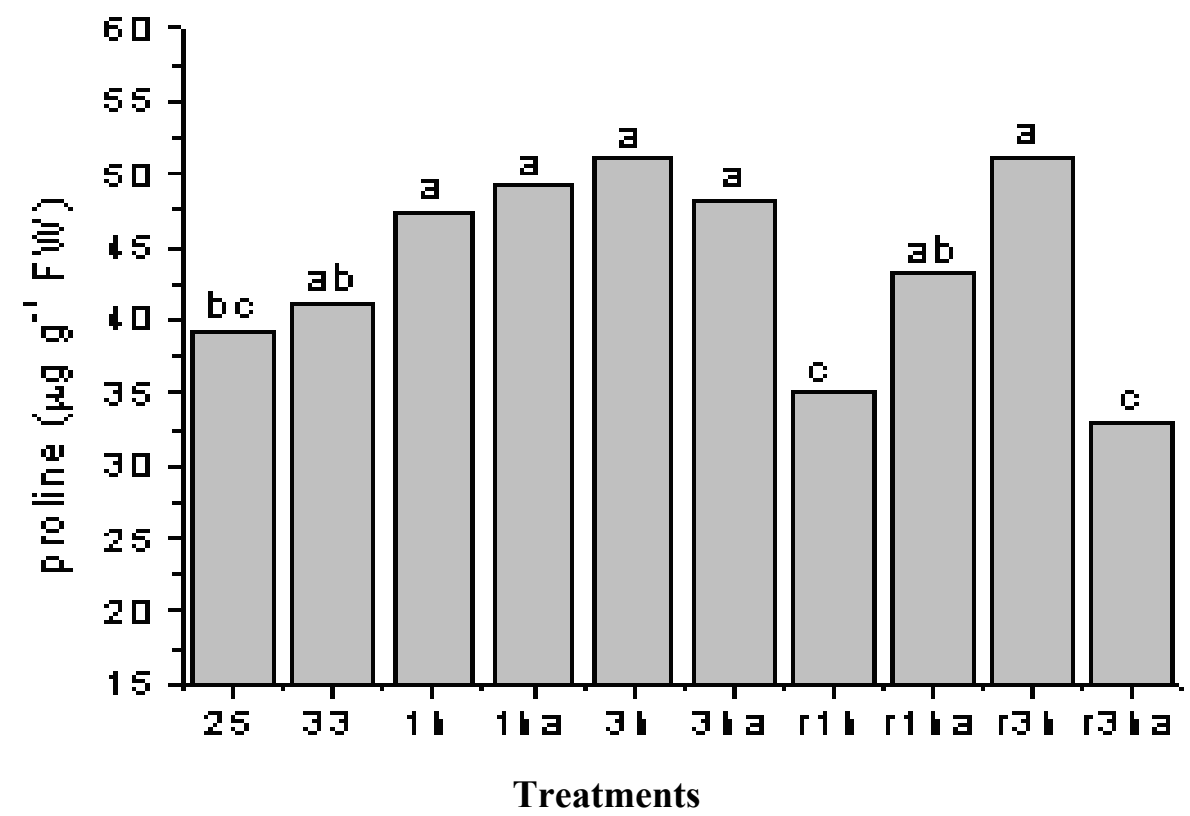

Figure 3 - Changes in proline concentration from Eucalyptus grandis shoots submitted to heat shocks. Small letters compare the mean of five repetitions (Tukey $p<0.05$ ). Treatments are detailed in Fig. 1. Each point represent the average of five replicates. 


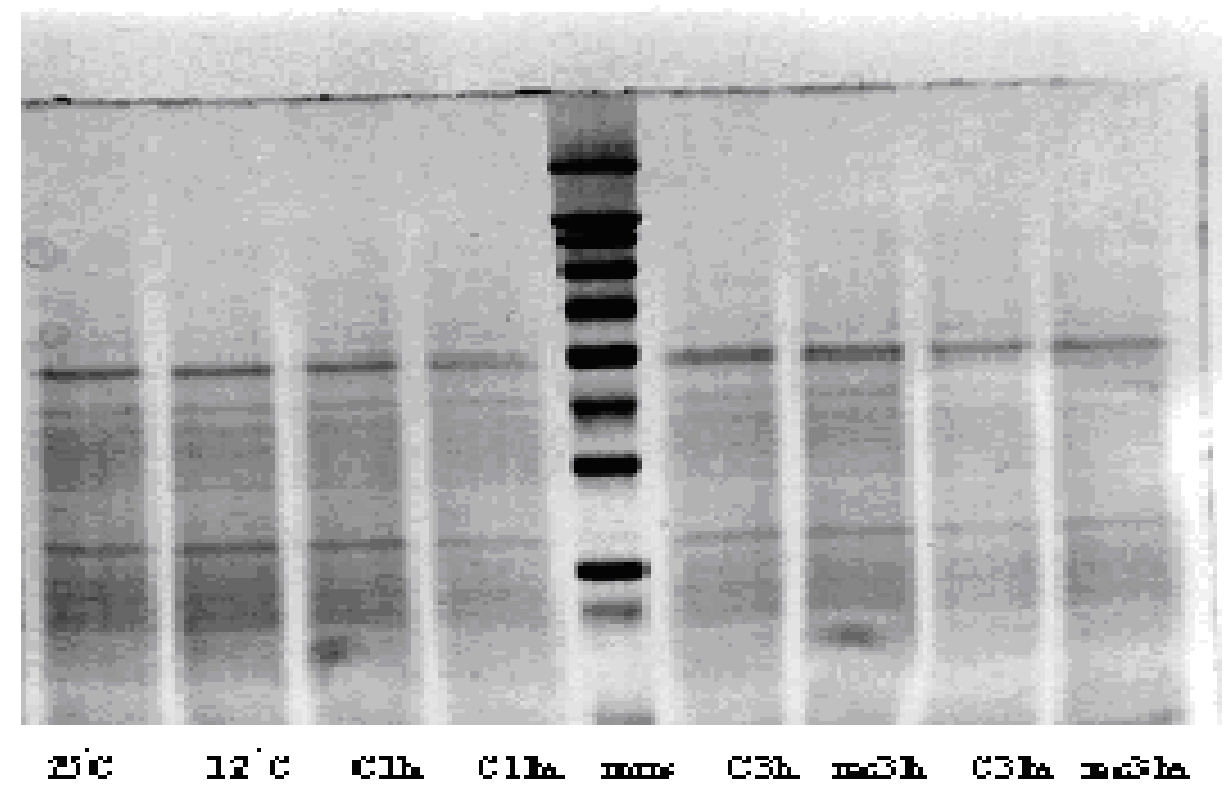

Figure 4 - SDS-PAGE of polypeptides from E. grandis shoots submitted to cold shocks. The $15 \%$ acrylamide gelwas stained with comassie $\mathrm{R} 3: 50 .\left(\mathrm{C} \mathrm{Ih}=\mathrm{Ih}\right.$ at $0^{\circ} \mathrm{C} ; \mathrm{C} 3 \mathrm{~h}=3 \mathrm{~h}$ at $0^{\circ} \mathrm{C} ; \mathrm{a}=\mathrm{acc} \lim$ ation, $\mathrm{rec}=$ recovery of the treatments $3 \mathrm{~h}$ at $0^{\circ} \mathrm{C}$ non acclimated $(\mathrm{rec}$ $3 \mathrm{~h}$ ) and acclimated (rec $3 \mathrm{ha}, \mathrm{mms}=$ molecular mass standards $\mathrm{hDa} ; 25^{\circ} \mathrm{C}=$ control before temperature shifts; $12^{\circ} \mathrm{C}=12 \mathrm{~h}$ acclimation at $12^{\circ} \mathrm{C}$.

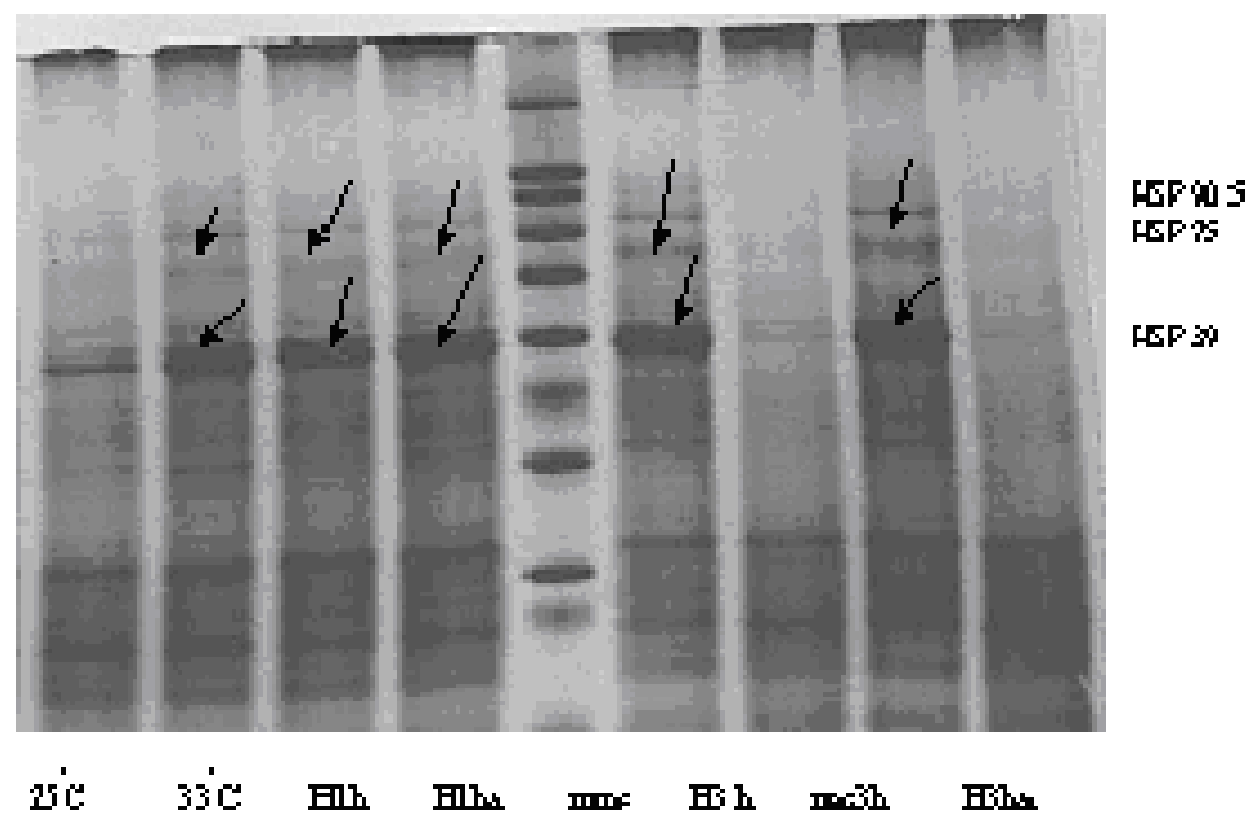

Figure 5 - SDS-PAGE of polypeptides from E. grandis shoots submitted to heat shocks. H1h= Ihat $41^{\circ} \mathrm{C} ; \mathrm{H} 3 \mathrm{~h}=3 \mathrm{~h}$ at $41^{\circ} \mathrm{C} ; \mathrm{a}=$ acclimation, $\mathrm{rec}=$ recovery of the treatments $3 \mathrm{~h}$ at $41^{\circ} \mathrm{C}$ non acclimated (rec $3 \mathrm{ha}$ ), $\mathrm{mms}=$ molecular mass standards $\mathrm{hDa} ; 25^{\circ} \mathrm{C}=$ control before temperature shifts; $33^{\circ} \mathrm{C}=12 \mathrm{~h}$ acclimation at $33^{\circ} \mathrm{C}$. 
When the shoots were returned to $25^{\circ} \mathrm{C}$ (recovery) the concentration of proline was estimated immediately after a $24 \mathrm{~h}$ period.

It was observed that proline levels were similar to the initial levels before heat shocks, except in non acclimated shoots submitted to $3 \mathrm{~h}$ of heat shock (Fig. 3). Moreover, proline contents of unacclimated shoots subjected to $1 \mathrm{~h}$ of heat shock without acclimation and the acclimated shoots subjects to $3 \mathrm{~h}$ of heat were lower than control level, indicating good recovery.

The eletrophoretic profiles of the proteins from shoot samples submitted to cold shocks reveal no qualitative differences among the treatments, as well as between the treatments and the $25^{\circ} \mathrm{C}$ control (Fig. 4). When analyzed by SDS/PAGE it was observed that both heat shock $\left(41^{\circ} \mathrm{C}\right)$ and acclimation $\left(33^{\circ} \mathrm{C}\right)$ treatments induced different protein pattern compared to that obtained at $25^{\circ} \mathrm{C}$ (Fig. 5), suggesting the synthesis of novel proteins. The apparent molecular masses of the proteins marked with arrows in the Fig. 5 were 90.5, 75.0 and $39.0 \mathrm{kDa}$, and they were not observed either in the shoots grown at $25^{\circ} \mathrm{C}$ or after the recovery period (Fig. 5, lanes 1, 7 and 9).

\section{DISCUSSION}

The quantitative differences in proline content observed between the control treatments of the experiments with high and low temperatures, could be accounted by the differences in the natural dynamics of plant metabolism as observed by Erdei et al. (1998). In that study the authors observed remarkable quantitative differences in carbohydrate concentrations and in enzymatic activity only because to different timing samples during the day.

Our results showed an increase of proline concentration in E. grandis shoots submitted to low temperature, with higher increases observed in the treatments acclimated under $12^{\circ} \mathrm{C}$. Since one of the factors involved in the protection against low temperatures stress include changes in the intracellular proline content (Larcher et al., 1973; Hare et al., 1998), which may have a cryopreservative function in plants (Santarius, 1992; Fretz et al. 1992), a 12h acclimation period at $12^{\circ} \mathrm{C}$ appears to have a qualitative rather than a quantitative effect on the shoot response to $1 \mathrm{~h}$ and $3 \mathrm{~h}$ cold shocks. A quantitative response was obtained by Chang et al. (2001) which reported that acclimation at $10^{\circ} \mathrm{C}$ for 2 to 3 days improved mungbean seedling tolerance to chilling at $4^{\circ} \mathrm{C}$. The authors observed that the concentration of free amino acids, e.g. proline, in the cell sap of $4^{\circ} \mathrm{C}$ chilled seedlings increased slightly compared to non chilled control, and the cold acclimation treatment induced an increase in the concentration of those solutes compared to non acclimated chilled plants. In this paper, the "recovery" period of $24 \mathrm{~h}$ at $25^{\circ} \mathrm{C}$ following the chilling treatments, had no effect on the proline content in acclimated E. grandis shoots, indicating that plant homeostasis mechanisms of the proline metabolism was damaged. In wheat seedlings, Weidner and Combrink (1979) reported that readaptation processes, concerning protein synthesis, took place within 48 hours after the recovery was initiated. In $E$. grandis, different recovery periods should be tested in order to elucidate this point.

Ukagi et al. (1999) reported that Morus bombycis trees acquired high freezing tolerance as a result of cold acclimation, with the amount of proteins from cortical parenchyma cells increasing in parallel with the process of cold acclimation. In Arabidopsis it was observed that hardening occured very rapidly, with a significant degree of tolerance being apparent after $12 \mathrm{~h}$ at low temperature (Gilmour et al. 1988). However, as expected in many tropical and subtropical species, $E$. grandis was not markedly tolerant to cold temperatures.

Similarly to cold treated E. grandis shoots, both acclimated and non acclimated shoots submitted to heat shocks showed an increase of proline concentration immediately after the thermal shocks. However, if the concentration of proline was determined after the recovery period $(24 \mathrm{~h}$ at $25^{\circ} \mathrm{C}$ ), no significant difference was observed compared to proline levels from shoots maintained at constant $25^{\circ} \mathrm{C}$, suggesting a recovery of the metabolism to the initial conditions (homeostasis), especially in acclimated shoots. Such a response was not observed in shoots submitted to cold shocks. Certain metabolic thermal compensation mechanisms (homeostasis) have been correlated with habitat thermal characteristics, with populations from thermally fluctuating environments exhibiting higher degree of thermal compensation than thermally stable populations (Tobiessem, 1976). If one consider homeostasis an adaptive characteristic, the results reported here suggested that E. grandis was more adapted to 
high temperature than to low temperature fluctuations. The $12 \mathrm{~h}$ acclimation period at $33^{\circ} \mathrm{C}$ appeared to improve the homeostasis capacity of the shoots, taking into account the changes of proline in the tissue. It has been known that acclimation influences thermal tolerance in plants as reported for several species (Howarth et al., 1997; Antikainen and Griffith, 1997; Gray et al., 1997). Yordanov et al. (1995) reported that young bean plants exposed for $5 \mathrm{~h}$ to high temperatures exhibited a marked increase in thermal tolerance of the photosynthetic apparatus. Kappen and Zeidler (1977) stated that the increase of heat tolerance, induced within few minutes, and a rapid heat hardening was an essential factor of the adaptive processes of heat tolerance.

The heat shock response is characterized by repression of normal cellular protein synthesis and induction of heat shock protein (HSP) synthesis, with a correlation between HSP and induced thermal tolerance in plants (Howarth and Oughan, 1993). Whereas the concentration of proline increased in E. grandis shoots submitted either to high or low temperature shocks, the protein patterns from cold and heat treated shoots differ from each other. The SDS-PAGE showed the presence of stress proteins immediately after $33^{\circ} \mathrm{C}$ acclimation and $41^{\circ} \mathrm{C}$ thermal shock, whereas no novel proteins were observed after exposure of the shoots to cold temperatures $\left(12^{\circ} \mathrm{C}\right.$ and $\left.0^{\circ} \mathrm{C}\right)$. Such differences in the plant response to cold and heat shocks were encountered in the literature, with alterations in gene expression in response to low temperatures being more diverse and usually less accentuated than the heat shock response (Howarth and Ougham, 1993). It was remarkable that thermal stress proteins were not observed after the recovery period in heat treated shoots, reinforcing the hypothesis that E. grandis could exhibit homeostasis under thermal stress.

In the present experimental conditions, the effect of the acclimation period on the homeostasis changed, depending on the type and duration of the temperature shock, as well as on the parameter evaluated. We observed that acclimation affected the homeostasis of the proline metabolism, particularly in shoots exposed 3 hours at $41^{\circ} \mathrm{C}$. Homeostasis was not affected by pre conditioning at $33^{\circ} \mathrm{C}$ in plants submitted to $1 \mathrm{~h}$ heat shock. Taking into account the homeostatic capacity, as evaluated in the present assay, the metabolism of E. grandis, considering specially soluble proteins and proline metabolism, appeared to be more affected by low than high temperatures although it could respond to both classes of stimulus.

\section{RESUMO}

As respostas às mudanças de temperatura de plantas aclimatadas e não aclimatadas de $E$. grandis cultivadas in vitro foram avaliadas considerando alterações dos níveis de prolina e proteínas solúveis totais. Análises de proteínas solúveis através de SDS-PAGE e prolina foram realizadas após $12 \mathrm{~h}$ a $12^{\circ} \mathrm{C}$ (aclimatação ao frio) ou a $33^{\circ} \mathrm{C}$ (aclimatação ao calor), e imediatamente depois dos choques térmicos a $41^{\circ} \mathrm{C}$ e $0^{\circ} \mathrm{C}$. Análises também foram realizadas após um período de $24 \mathrm{~h}$ depois dos choques térmicos (período de recuperação). $\mathrm{O}$ tratamento de temperatura a $0^{\circ} \mathrm{C}$ não alterou $\mathrm{o}$ padrão de proteínas nas plantas aclimatadas e não aclimatadas, entretanto a temperatura baixa induziu altos níveis de prolina, que se mantiveram relativamente altos após o período de recuperação. Três novas proteínas $(90,5,75$ e $39 \mathrm{kDa})$, provavelmente HSPs, foram observadas nas plantas aclimatadas e não aclimatadas submetidas às temperaturas altas. As plantas expostas a $41^{\circ} \mathrm{C}$ foram capazes de recuperar-se dos choques após o período de recuperação, entretanto não houve recuperação completa das plantas expostas às baixas temperaturas. $\mathrm{O}$ efeito da aclimatação sobre a recuperação (homeostasis) pode variar dependendo do parâmetro avaliado, tipo e duração do choque térmico.

\section{REFERENCES}

Arora, S. and Saradhi, P. (1995), Light-induced enhancement in proline levels in Vigna radiata exposed to environmental stress. Aust. J. Plant Physiol., 22, 383-386.

Antikainen, M. and Griffith, M. (1997), Antifreeze protein accumulation in freezing-tolerant cereals. Physiol. Plantar., 99, 423-432.

Barros, N. F.; Novais, R. F.; Cardoso, J. R. and Macedo, P. R. O. (1990), Relação solo-eucalipto. Universidade Federal de Viçosa, Viçosa.

Bates, L. S.; Waldren, R. P. and Teare, I. D. (1973), Rapid determination of free proline for water-stress studies. Plant and Soil, 39, 205-207.

Chapin Iii, F. S. (1991), Integrated responses of plants to stress. BioScience, 41, 29-36. 
Chang, M.W, Chen, S.L., Lee, C.F. and Chen, Y.M. (2001), Cold-aacclimation and root temperature protection from chilling injury in chilling-sensitive mungbean (Vigna radiata L.) seedlings. Bot. Bull. Acad. Sin., 42, 53-60.

Correia, D. (1993), Crescimento e desenvolvimento de gemas na multiplicação de Eucalyptus spp in vitro em meio de cultura líquido e sólido. MsC. Dissertation, ESALQ/USP, Piracicaba.

Erdei, L.; Szegletes, Z.; Barabás, K.N.; Pestenácz, A.; Fülöp, K.; Kalmár, L.; Kovács, A.; Tóth, B. and Dér, A. (1998), Environmental stress and the biological clock in plants: changes of rhythmic behavior of carbohydrates, antioxidant enzymes and stomatal resistance by salinity. J. Plant Physiol., 152, 265-271.

Fretz, A.; Jahne, A. and Lorz, H. (1992), Cryopreservation of embryonic suspension cultures of barley (Hordeum vulgare L.). Bot. Acta, 105, 140145.

Gimalov, F.P.; Chemeris, A.V. and Vakhitov, V.A. (1996), Synthesis of cold shock proteins in wheat tribe seedlings of the family Poaceae. Russ. J. Plant Physiol., 43, 228-231.

Gray, G.R.; Chauvin, L.-P.; Sarhan, F. and Huner, N.P.A. (1997), Cold acclimation and freezing tolerance. Plant Physiol., 114, 467-474.

Hare, P.D.; Cress, W.A. and Van Staden, J. (1998), Dissecting the roles of osmolyte accumulation during stress. Plant, Cell and Envir., 21, 535-553.

Howarth, C.J. and Oughan, H.J. (1993), Geneexpression under temperature stress. New Phytol., 125, 1-26.

Howarth, C.J. and Skot, K.P. (1994), Detailed characterization of heat shock protein synthesis and induced thermotolerance in seedlings of Sorghum bicolor L. J. Exper. Bot., 48, 1353-1363.

Howarth, C.J.; Pollock, C.J and Peacock, J.M. (1997), Development of laboratory-based methods for assessing seedling thermotolerance in pearl millet. New Phytol., 137, 129-139.

Jacobs, M. (1976), Eucalypts for planting. FDA Organization of the United Nations, Rome. 398 pp.

Kappen, L. and Zeidler, A. (1977), Seasonal changes between one and two phasic response of plant leaves to heat stress. Oecologia, 31, 45-53.

Larcher, W.; Heber, V. and Santarius, K. A. (1973) Limiting temperatures for the life functions. In: $\mathrm{H}$. Precht, J. Christophersen, H. Hensel, and W. Larcher (Ed.).Temperature and life. Springer-Verlag, Berlin, pp. 195-231.

Møller, A.P. and Swaddle, J.P. (1997), Asymmetry, developmental stability, and evolution., Oxford University Press, Oxford.

Nilsen, E. T. and Orcutt, D. M. (1996), Physiology of plants under stress: abiotic factors. John Wiley and Sons, New York, pp. 445-514.
Sabehat, A.; Weiss, D. and Lurie, S. (1996), The correlation between heat-shock protein accumulation and persistence and chilling tolerance in tomato fruit. Plant Physiol., 110, 531-537.

Santarius, K. A. (1992), Freezing of isolated thylakoid membranes in complex media. VIII. Defferential cryoprotection by sucrose, proline and glycerol. Physiol. Plantar., 84, 87-93.

Souza, G. M.; Gonçalves, A. N. and Machado Neto, N. B. (1999), Crescimento in vitro de progênies de Eucalyptus camaldulensis Dehn. Sob condições de deficiência hídrica. Scien. Agric., 56, 557-562.

Tobiessen, P. (1976), Thermal acclimation of dark respiration in coastal and desert populations of Isomeris arborea. The Am. Mid. Nat., 96, 462-467.

Ukagi, N., Kubawara, C., Takezawa, D., Arakawa, K., Yoshida, S. and Fujikawa, S. (1999), Accumulation of small heat shock protein homologs in the endoplasmatic reticulum of cortical parenchyma cells in mulberry in association with seasonal cold acclimation. Plant Physiol., 120, 481-489.

Weidner, M. and Combrink, G. (1979), Phenotypical temperature adaptation of protein synthesis in wheat seedlings. Plant Physiol., 64, 144-149.

Received: August 26, 2002; Revised: February 18, 2003; Accepted: August 08, 2003. 